\title{
VILFREDO PARETO, TRATTATO, AND ITALIAN SCHOOL OF FISCAL SOCIOLOGY
}

\author{
Haydar Lütfü EJDER ${ }^{1}$
}

\author{
Ali Çelen ERDURAN²
}

\begin{abstract}
In this study Vilfredo Pareto, whose economic and political views had been changed in his life time due to the transformation of political environment he had lived in, and as a result who had achieved to introduce one of the paradigms of sociological theory will be analized. And in last section, Pareto inspired Italian Fiscal School which puts political theory in center of its analysis will be explained.
\end{abstract}

Keywords: Pareto, Public Economics, Theory of Elits, Fiscal Sociology

JEL Code: A-14, H-30.

\section{Introduction}

As a conscious and sensible citizen we are all affected by the political atmosphere and political debates that surround us. But as professionals studying thescience of public finance we nearly neglect the inter-disciplinary bounds between theory of public finance and political theory. In this study Vilfredo Pareto, whose economic and political views had been changed in his life time due to the transformation of political environment he had lived in, and as a result who had achieved to introduce one of the paradigms of sociological theory will be analyzed. And in final section, Pareto inspired Italian Fiscal School which puts political theory in center of its analysis will be explained.

\section{Vilfredo Pareto: His Life and Development of His Thought}

Pareto, whose name can often be seen in public economics books, was not just a pure economist, but was also founder of the General Sociology paradigm, in which social phenomenon are analyzed in a holistic way. A brief look at his life gives us some clues about how an academician, who devoted first years of his career to pure economic theory turned out to be a sociological paradigm founder as a result of his frustration against the changing political atmosphere of his life time.

Born in 1848, Vilfredo Federico DamascoPareto, was son of a French mother an Italian marquis father. Pareto studied classics and engineering at the Polytechnic Institute of Turin. His graduation thesis, "The Fundamental Principles of Equilibrium in Solid Bodies" provided him with the basic model he would later use in his study of economics and society (Femia, 2005: 6). He first took a job as an engineer in a mine company where made business trips to England and Scotland. In those trips he made himself acquainted with political economy and he started to form his first political views (Marshall, 2007: 11). In time Pareto dabbled in radical politics, expressing extreme views in support of democracy, free trade and disarmament (Fermia, 2005: 7).

1 Dr., Ankara Hacı Bayram Veli University, F.E.A.S., Department of Public Finance, haydar@gazi.edu.tr

2 Res. Asst., Ankara Hacı Bayram Veli University, F.E.A.S., Department of Public Finance, acerduran@gmail.com 
Besides forming his political views, Pareto also started his academic career. In the time being he draw away from Classical Economic School of Smith, Ricardo and Mill and became acquainted with Neo Classical Economic School. With the support of MaffeoPantaleoni - the most important advocate of mathematical analysis based Neo Classical School of Jean Walras in Italy - Pareto appointed a position in Lausanne University. (Bourkenau, 1936: 14). In Switzerland he produced his two volume "Coursd'EconomicPolitique" in which he analyzed the conditions of economic equilibrium and he expressed his views on free trade, state intervention and liberalism (Femia, 2005: 8). In the mean while he also continued to assault Italian political system and government (Femia, 2005: 8)

In 1907 he retired from his chair in Lausanne, partly because of a heart condition and partly because of his disenchantment with the discipline of economics (Femia, 2005: 10). But even before his retirement, between mid-1890's to year 1900, his political stance had changed radically and he became an anti-liberal and anti-democratic. After his retirement Pareto fully dedicated himself to political, philosophical and social issues and to develop a social system focusing on social interaction. He published his masterpiece "Trattato di SociologiaGenerale" - translated to English as "The mind and Society" - in 1916. Though he tried to keep distance and warn them to avoid censorship and despotism, Italian Fascists showered him with honors, because of his anti-democratic and anti-marxist views (Femia, 2005: 11). He died in 1923 a mere ten months into Mussolini's reign, and before the uglier aspects of fascism became obvious.

\section{Economic Approach of Pareto}

In welfare economics we often see the name Pareto. Concepts like first theorem of the welfare economics, Paretian criteria or Pareto improvement are discussed in detail in all public economics and microeconomics text books. In our study however those subjects will not be repeated but we will focus on the formation of the Pareto's economic views.

In the first place Pareto developed his own economic theory. His economic studies were aimed at verifying that laissez-faire is apolicy maxim that is consistent with a general economic theory founded on scientific (mathematical) principles (McLure, 2001: 41).

For Pareto, science of economics separates into two branches. In the first one of these two branches - which Pareto called "pure economic theory" - there is a deductive economic research field which assumes the existence of a homoeconomicus whose actions are hedonistic in everything. The researchers in this field make predictions about a social structure by aggregating the actions of these homoeconomicus' (McLure, 2001: 41).

Second branch is applied or experimental economics. In this research field, one extracts economic models based on experiences or tendencies, and then comparative analysis with real world data is made.

According to Pareto, in first branch an idealized, desirable economic world is analyzed. While in second branch factors distracting this ideal system are investigated. For McLure (2001) such a design of economic analyses depends on Pareto's engineering education past. Just as first designing a machine and then testing its workability in real world. McLure names this economical approach "the mechanical analogy" (McLure, 2001: 41). 
At the center of Pareto's pure economic theory there is the concept of equilibrium. Like in the proposition "ones welfare cannot be improved without deterioring the other's", equilibrium is a change to one condition results in other changes that act in the opposite direction (McLure, 2007: 26). But this term is only related to his pure economic theory. In experimental economics Pareto concentrates on the facts, that changes or disturbs this theoretical equilibrium.

Pareto's main aim was to limit the research field of pure economic theory and widen the fields of experimental economics and other experimental sciences which put the real world data at the center of analysis (McLure, 2001: 25). Because, according to him one experimental discipline can only analyze a specific part of a social phenomenon and by comparing different disciplines' evidences we can be able to reach a much more realistic explanation of that certain social phenomenon (McLure, 2001: 26).

Next, Pareto introduced a distinction between ophelimity and utility. The abstract quality of acts that lead to physical, intellectual and moral development is termed "utility", whereas ophelimity is a subclass of utility that is limited to the subjective and abstract quality of acts that satisfy a need or desire (McLure, 2007: 26). In economics, economic utility concerns the development of material wellbeing and economic ophelimity concerns the satisfaction of material needs and desires (McLure, 2007: 27). For Pareto utility is an indefinite and obscure concept. Moreover the term utility may be considered in terms of individual, the community or society as a hole (McLure, 2001: 42). On the other hand for Pareto ophelimity is a more scientific concept because individual need and desires are observable and measurable (McLure, 2001: 43).

The distinction between the terms utility and ophelimity don't have any importance in today's highly specialized science of economics, because inter-disciplinary studies today are limited. But this distinction is the center of Pareto's general social system because the concepts of logical and non-logical actions depend on this very distinction. Where maximisation of ophelimity is related to logical consumption or production decisions of economic actors; maximization of utility is a sociological concept and related to individuals' non-logical decisions over their general welfare.

\section{Pareto's General Sociology}

First of all, according to our view, Pareto's general sociological system doesn't aim to analyze an ideal social system but, it is the positive analysis of the corrupted and degenerated political and social system of his times. In other words his opposition against liberal parliamentary system is not on philosophical or ideological level but his objection is against its real life appearance.

Figure (1) shows the Paretian social equilibrium, which results from the interaction between economic, political and socio-behavioralequilibrium. 
Figure 1. Pareto's Sociological Analysis of Equilibrium

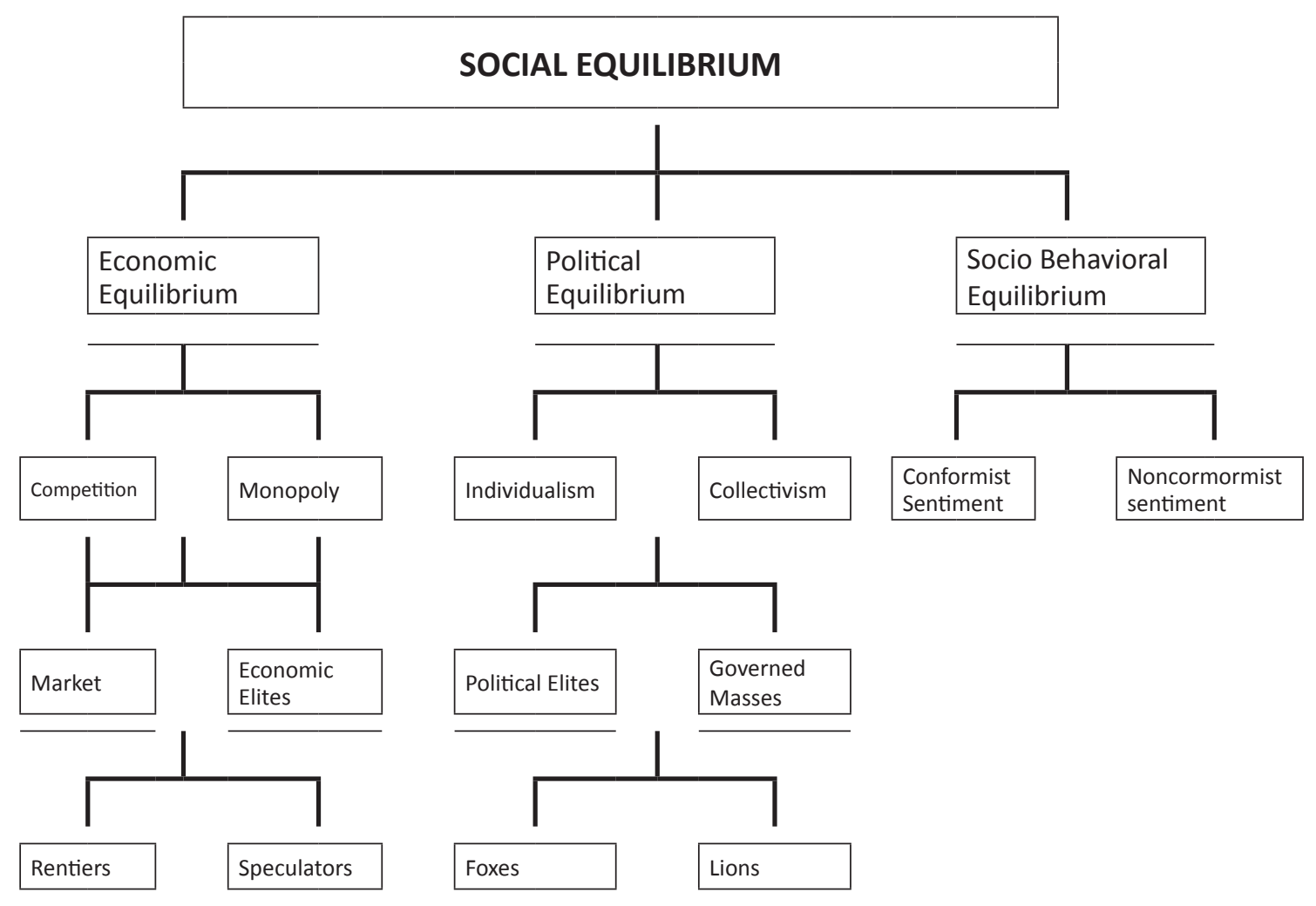

Source: McLure $(2007,44)$.

Economic equilibrium is determined by the principles of economic theory. But the other two, political and socio-behavioral equilibriums are the experimental parts of the social equilibrium. In other words, these are the branches of a general system where Pareto's experiences and observations made him loose his fate in liberal - democratic system.

Different parts of the general sociology were produced in different periods of Pareto's life and his work was completed in 1916. For example he developed economic theory in his youth years where as elite theory was developed in his years in Laussane University or socio-behavioral equilibrium was produced in his retirement years (McLure, 2007: 27; Femmia, 2005: 16). But for the sake of logical integrity, Pareto's system will be handled following Richard Aron's approach, not by its conceptual developmental chronology.

Pareto's general sociology is an agent based, micro-sociological approach. It first starts with defining the concepts of logical and non-logical actions. For Pareto logical actions are the ones where the means - end relation in objective reality must correspond to the means - end relation in the mind of actor (Sarp, 2013: 95). Whereas non-logical actions are the ones which, means - end relation in objective reality doesn't correspond to the means - end relation in the mind of actor. One point must be made clear that, non-logical actions are not illogical actions (Sarp, 2013: 91). In other words, if logical and illogical actions are two opposite points (like black and white), non-logical actions are the points fall between these opposite points (like different shades of grey). 
According to Pareto, accept from limited economic actions that can be analyzed in terms of ophelimity, nearly all every day actions of an individual are non-logical.

Non-logical actions of an individual depend on two concepts, residues and derivatives. Residues are basic and mostly non logical behavioral motives, whereas derivatives are the rationalization, are the effort to explain residues in a logical sense (Sarp, 2013: 103). In other words depending on the "a human is not a rationale but a rationalizing animal" motto, derivatives are the elements of rationalization.

In Paretian sociology there are 6 residues and 4 derivatives. Residues are,

i) The Instinct for Combinations

ii) Group Persistence

iii) The Compulsion to Express Sentiments by External Acts

iv) Sociality

v) Residues of Integrity

vi) Sexual Residues.

Whereas derivatives are;

i) Assertion,

ii) Authority,

iii) Sentimental Ones

iv) Verbal Proofs.

The first aim of the Paretian sociology is to study non-logical actions as non-logical actions, and not to lend a logical appearance tonon-logical behavior (Aron, 1967: 115). For example in Public Choice Theory voting behavior is explained as a politically motivated utility maximization. As for Paretian sociology, an individual's voting behavior is determined by his residual actions and he rationalizes this action by derivatives.

This behavioral system leads us to the second part of the Paretian sociology theory, the elite theory. As shown in Figure (1) two of the three factors of a social equilibrium are economic and political equilibriums. In a social system, economic and political elites try to keep the sociobehavioral system in equilibrium. They do this by addressing residual motives of the individuals (McLure, 2007: 125).

In Paretian sociology there are two kinds of elites, social elites and political elites. Social elites are the aggregate of economic and political elites. But the main actor here is political elites. They are the governing class and they determine who the economic elites shall be. And by this way they create a totalclass of social elites. Nature of elites forms the society or the social system (Sarp, 2013: 104). Elites use two methods in governing society, force and guile. If the masses allow themselves to be manipulated by elites, it is either because the elites control the means of force or because they succeed in convincing the masses (Aron, 1971: 159). A legitimate government is one which has succeed in persuading the many (Aron, 1971: 159)

According to Pareto history of societies is the history of political elites which appear, struggle, take power, enjoy that power, fall into decadence and, to be replaced by other political elites (Aron, 1971: 162). And each political elite tries to create his own social elite group by influencing the economic elites of the society. This is where the link between Paretian sociology and public finance appears. 


\section{Paretian Sociology and Italian Fiscal Sociology}

Citing Mauro Fassiani, McLure (2007) declares that there were three main stream public finance theories in Italy in early 1900's. First Viti de Marco and Mazzola's Neo Classical public finance approach. Second Murray, Loria and Puviani's political theory approach and third Borgatta and Sensini's sociological approach. Here the third one, Borgatta and Sensini'sparetian sociology based fiscal sociological approach will be analysed

Based on his pure economic theory, Pareto made great contributions to the theory of public economics. But he never made any direct contribution to the field of fiscal sociology. On the other hand his influence advanced through the works of his ex-students and followers, Borgatta and Sensini. These two, today are thought to be the founders of Italian Fiscal Sociology approach (McLure, 2007: 121 - 122).

Italian fiscal sociology focuses the role of fiscal policy in maintaining social equilibrium. Political elites may use fiscal policy instruments in two ways. First they use such instruments like fiscal incentives or tax benefits to create their own economic elites. Second they can use fiscal instruments in order to affect the socio-behavioral equilibrium. Here the main purpose is to persuade masses by deceiving them with fiscal policy. Targeted transfers or changing the burden of taxation from direct taxes to indirect ones are examples of these policy instruments.

Figure (2) shows the Sensini's classification of public finance in accordance with the Paretian sociological approach. Technical public finance for Sensini is the field of public finance where no inter-disciplinary studies are made. Examining or evaluating tax or budget laws are examples of this field. Analytic public finance is the field where relation between pure economic theory and theory of public finance is taken into account. Finally synthetic public finance emphasize on relation between theory of public finance and political theory whereas action theory refers to relation between fiscal politics and their effects on individual behaviors.

Figure 2. Sensini's Classification of Public Finance

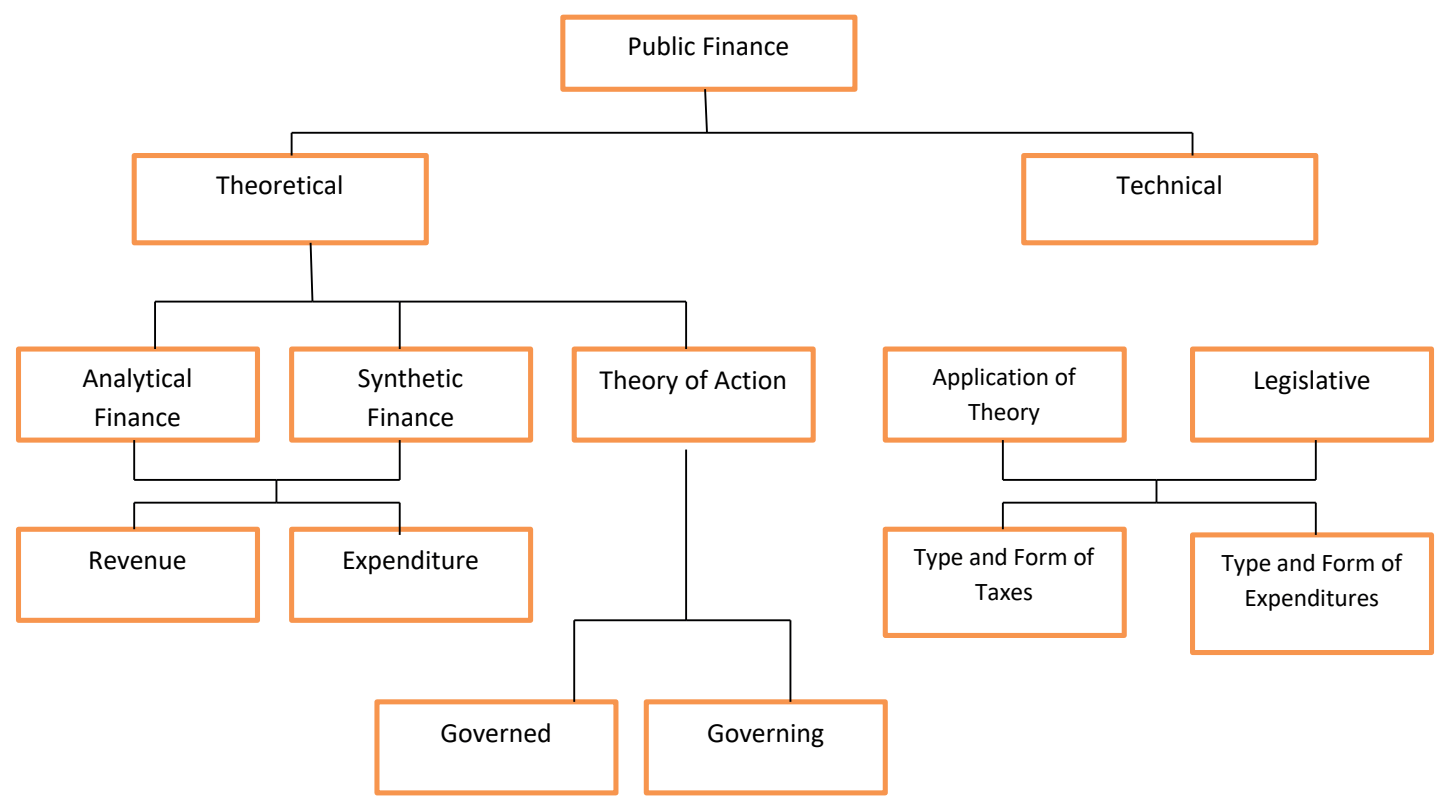

Source: McLure $(2007,129)$ 


\section{Conclusion}

As a result according to Paretian fiscal sociology or Italian fiscal sociology, apart from technical and analytical ones, all branches of public finance analysis should depend on logical and nonlogical behavioral system of Paretian general sociology. Fiscal decision making processes should be re-accounted according to the political elites' different political motives. Some of our early theoretical or experimentalfindings regarding analytic or technical public finance may well be changed, if can re-set our perspective on the theory of public finance. Beside this, theories of technical and especially analytical public finance must be reviewed in order them not to be part of apolitical deceiving process.

\section{References}

\section{Journals/Periodicals;}

Sarp, Ç. (2013). "Pareto'yu Okumak Mantıklı Olmayan Davranış ve Seçkinler Teorisi", Sosyal Bilimler Dergisi, Cilt: 3, Sayı: 2, s. 91-113.

\section{Books;}

Aron, R. (1971). Main Currents in Sociological Thought: Durkheim, Pareto, Weber, London, Penguin Books Ltd.

Borkenau, F. (1936). Modern Sociologists: Pareto, London, Chapman and Hall.

Femia, J. V. (2006). Pareto And The Political Theory, Routledge Studies in Social and Political Thought, Newyork, Routledge, Taylor \& Francis Group.

Marshall, A. (2007). Vilfredo Pareto's Sociology: A Framework for Political Psychogy, Hamshire, Ashgate Publishing Limited.

McLure, M. (2001). Pareto Economics and Society: The Mechanical Approach, Routledge Studies in Economic History, London, Routledge, Taylor \& Francis Group.

McLure, M. (2007). The Paretian School And Italian Fiscal Sociology, New York, Pallgrave MacMillan. 